

\section{Flammable Gas and Steam Release Controls for WRSS Operation, Project W-320}

\section{S. D. Estey}

WHC, Richl and, WA 99352

U.S. Department of Energy Contract DE-AC06-87RL10930

$$
E \Delta T-615296
$$

EDT/EEN: 610265-

UC: 2030

Org Code: 74A10

Charge Code: D2ME6

B\&R Code: EW3130010

Total Pages: 27

Key Words: Steam Release, Gas Retention, Gas Release, Tank Leve1, Specific Gravity, Controlled Level Sluicing.

Abstract: This report documents operational controls to be incorporated into the Process Control Plan for Project W-320, Tank 241-C-106 (C-106)

sluicing. The controls are based upon various technical analyses regarding prevention of potential hazards formed by uncontrolled releases of flammable gas or steam from the wastes contained within the Waste Retrieval Sluicing System. The retrieval approach calls for the sequenced removal of waste from tank $C-106$ in volume increments of 25,000 gallons. A holding or waste monitoring period is specified upon removal of each 25,000 gallon waste volume increment. The waste behavior which must be observed during the monitoring period is stated. These behavioral specifications must be satisfied to allow the retrieval effort to progress to the removal of the next waste volume increment.

TRADEMARK DISCLAIMER. Reference herein to any specific comercial product, process, or service by trade name, trademark, manufacturer, or otherwise, does not necessarily constitute or imply its endorsement, recommendation, or favoring by the United States Government or any agency thereof or its contractors or subcontractors.

Printed in the United States of America. To obtain copies of this document, contact: WHC/BCS Document Control Services, P.O. Box 1970, Mailstop H6-08, Richland WA 99352, Phone (509) 372-2420; Fax (509) 376-4989.
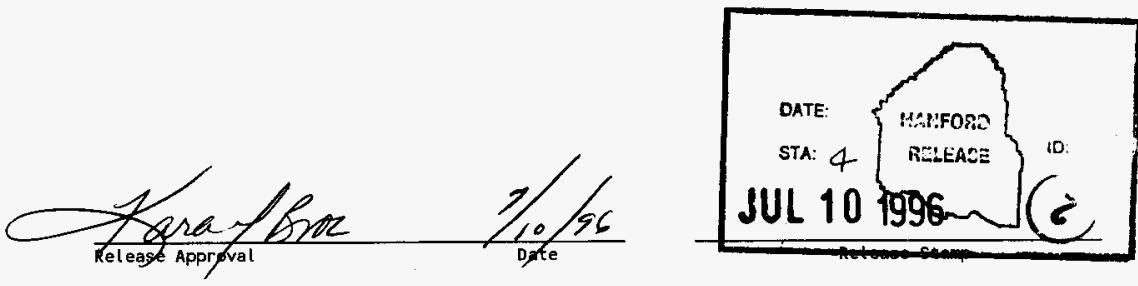

Approved for Public Release 
WHC-SD-W320-TI-007

Revision 0

\title{
FLAMMABLE GAS AND STEAM RELEASE CONTROLS FOR WRSS OPERATION, PROJECT W-320
}

\author{
Ju1y 1996
}

S. D. Estey

Prepared by

Westinghouse Hanford Company

Richland, Washington 
WHC-SD-W320-TI-007

Revision 0

TABLE OF CONTENTS

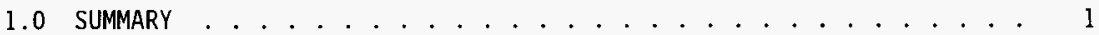

2.0 DISCUSSION . . . . . . . . . . . . . . . . . 2

2.1 Tank $C-106$ Steam Void Release .............. 2

2.2 Tank C-106 Gas Plume Generation ............. 2

2.3 Tank AY-102 Gas Retention/Release Behavior. . . . . . . . . . 3

3.0 OPERATIONAL CONSIDERATIONS ................. 5

3.1 Basic Control Actions .............. . . 5

3.2 Summary of Process Control Levels ............ . 7

3.3 Measurement of Incremental Waste Retrieval . . . . . . . . . . 8

3.4 Monitored Parameters During Hold Periods . . . . . . . . . . . 12

3.5 Data Requirements to Determine Satisfactory Completion of Hold Period................ 12

4.0 CONCLUSIONS AND RECOMMENDED OPERATIONAL CONTROLS . . . . . . . . 15

5.0 REFERENCES ..................... 24

\section{LIST OF TABLES}

1. Waste Behavior Specifications for Associated Waste Volume Retrieval

Increment . . . . . . . . . . . . . . . . . . . . 8

2. Predicted Waste Retrieval as a Function of Measured Process

Parameters .................... . . 11

3. Parameters and Limits ................. . . 22

\section{LIST OF FIGURES}

1. Predicted Maximum Tank AY-102 Level as a Function of Percentage Tank

C-106 Waste Retrieval and Supernate Temperature . . . . . . . . 16

2. Predicted Supernate Specific Gravity as a Function of Percentage Tank

C-106 Waste Retrieval and Supernate Temperature . . . . . . . . 17

3. Predicted Increase in Maximum Tank AY-102 Level as a Function of

Percentage Tank C-106 Waste Retrieval and Supernate Temperature . . 18

4. Predicted Increase in Supernate Specific Gravity as a Function of

Percentage Tank C-106 Waste Retrieval and Supernate Temperature . . 19 
WHC-SD-W320-TI-007

Revision 0

\subsection{SUMMARY}

This document outlines operational controls to be incorporated into the Process Control Plan for Project W-320, Tank 24l-C-106 Sluicing. Gas and vapor emission concerns are associated with the proposed retrieval method. One concern is the potential for generating a gas plume or steam release as a result of the rate of waste removal from tank $C-106$. This could result if saturated or gasified regions of waste are exposed by sluicer operation causing a mechanical disturbance of the waste. A second concern is the ability to detect a developing gas retention condition in tank AY-102, which would usually be masked by an excessive rate of waste deposition in the tank during routine sluicing operations. The amount and condition of the solids deposited in tank AY-102 are thought to play a significant role in gas retention in the tank waste as well as in the probability of inducing subsequent episodic gas releases.

A strategy is developed by which routine process measurements can be used to indicate the amount of waste retrieved from tank C-106. This strategy provides a means to determine when the sluicing system should be shutdown to allow for additional waste analysis. This document references the safety concerns of various supporting waste analys is documents, provides methods of measuring the waste conditions believed to indicate the onset of the safety concerns, and integrates the recommended anaiys is methods for determining the existence of a safety concern. The result is a recommendation of operational controls used to indicate that a significant amount of waste retrieval has occurred and that sluicing should be halted, as well as a recommendation of the actions to be taken during the subsequent sluicing system shutdown for waste analysis. A path forward for continued waste retrieval is presented based on the outcome of the waste analysis. 
WHC-SD-W320-TI-007

Revision 0

\subsection{DISCUSSION}

The dynamic effects of the waste retrieval operation make possible gas and steam release scenarios. The waste in tank $\mathrm{C}-106$ is though to have some probability of containing trapped gas and/or regions of steam voids which might become exposed by the sluicing action. Additionally, transfer of solids to tank AY-102 may create additional gas retention problems.

\subsection{Tank C-106 Steam Void Release}

Because of to radioactive thermal effects and heat transport mechanisms of tank C-106 waste (Bander, Crea, Ogden 1996 (Draft)), the rate of agitation or removal of the waste may cause exposure and release of steam voids from the solids. The sluicing action may expose saturated regions of the waste solids, therefore, it is predicted that rapid sluicing can result in steam generation in the waste. By limiting the rate of waste removal, ensuring supernate contact with the waste, and including periodic waste monitoring or hold periods during the removal, steam bumps will be avoided. The recommendation is that a controlled, step-wise or incremental retrieval be carried out with sufficient hold periods to allow any temperature distributions in the waste to decay to the point where the waste is considered completely subcooled. By limiting the initial waste retrieval, ensuring a continuous supernate cover to promote heat transfer, and incorporating planned inactive periods to allow for thermal equalization in tank $C-106$, a steam flash from the waste will be unlikely. The inactive or hold period allotted for waste monitoring is two weeks in duration. This ensures the heat transport mechanisms in the waste are sufficient, over the period, to essentially achieve thermal equilibrium. After a prescribed series of controlled and monitored waste removals from tank C-106, the probability of a steam release from the waste will have diminished to the point of being considered incredible.

These findings suggest a retrieval approach in tank $C-106$ which conservatively limits the rate and amount of short term waste removal. After sufficient heat load and thermal resistance has been removed from the waste, and the waste temperature distribution is entirely subcooled with respect to the tank headspace, steam release concerns from tank $\mathrm{C}-106$ will have been el iminated. At this point, steam release concerns will no longer constrain tank $C-106$ waste removal.

\subsection{Tank C-106 Gas Plume Generation}

The act of agitating the waste by sluicing action is thought to be capable of triggering a plume gas release provided the gas is trapped in tank waste (Estey 1996a). The sluicer is capable of disturbing a relatively large volume of tank C-106 waste in short order - up to an estimated 27,000 gallons in 15 seconds. If trapped gas is uniformly distributed through the low shear 
WHC-SD-W320-TI-007

Revision 0

strength, high heat sludge, this degree of agitation could potentially release 100 SCF of hydrogen over a large area of the waste surface. Estimates of the total inventory of trapped gas currently in tank C-106 are on the order of 500 SCF, which is conservatively assumed to be composed of hydrogen. The release of the total amount of trapped gas is unlikely because of the expected uniform distribution of the gas in the waste, the relatively long emission times estimated for the release, and the large surface areas over which the gas would be released.

This said, an analysis of potential burn scenarios resulting from the gas plume generated by release of the entire estimated volume of trapped gas in tank C-106 yielded a maximum pressure pulse of less than 2 psi (Plys 1996 (Draft)). The assumptions incorporated in the analysis are divorced from a cause-effect relationship because of tank C-106 sluicer operation. As such, the plume burn scenario does not result in specifications for controls upon operation of the Waste Recovery Sluicing System (WRSS), but falls in the realm of the project safety analysis.

\subsection{Tank AY-102 Gas Retention/Release Behavior}

Recent analysis of DST waste parameters has postulated new relationships between those parameters and the probability of episodic gas release behavior of the tank waste (Estey \& Guthrie, 1996). These relationships were further investigated for application to the sluicing retrieval of tank C-106 wastes (Estey 1996b, Barton 1996). In these investigations, best estimates of the insoluble mass fraction of the resultant slurry deposited in tank AY-102 indicate that significant void fraction growth, also known as solids fluffing, will occur at least upon initial settling. As a result, the volume (and depth) of the settling solids will, for an undetermined period of time, be such as to suggest conditions conducive to gas retention and subsequent episodic release unless restrictions are placed on the amount of solids transferred. It was estimated (Barton 1996) that limiting the amount of tank C-106 waste retrieval to one-half of the total waste inventory will give reasonable assurance that episodic gas release behavior will not be induced in tank $A Y-102$.

These findings suggest that limiting, at least initially, the amount of waste removal from tank $\mathrm{C}-106$ to $50 \%$ of the total will 1 argely prevent gas retention and subsequent episodic release regardless of the slurry settling behavior. Once this level of waste recovery has been achieved, the WRSS pumps will be shutdown and the level in tank AY-102 will be monitored for evidence of slurry growth. After a reasonable waiting period a number of outcomes are possible: 
WHC-SD-W320-TI-007

Revision 0

Outcome 1: No slurry growth is noted and significant solids settling occurs This is the desired result and indicates that no gas retention is evident. In addition, the solids have settled to the point were the reasons for stopping at $50 \%$ waste recovery are no longer valid. In this case, recovery can continue, if needed, in a stage-wise manner, with confidence that any gas retention condition that appears to develop is likely to be a temporary phenomena, and will self-mitigate as further solids settling occurs in tank AY-102.

Outcome 2: No slurry growth is noted but no significant solids settling occurs This outcome indicates that no gas retention is evident, but, the hindered solids settling indicates that the tank may be closer to a critical limit (Estey 1996b). At this point, it may be advisable to determine if sufficient waste recovery has occurred to mitigate the high heat tank safety issue, or to continue waiting to see if additional solids settling occurs. If further solids settling does not occur and the high heat waste tank safety issue has not been mitigated, it may be decided to continue with staged sluicing with the expectation that slurry growth conditions are imminent and the need for active mitigation is anticipated.

Outcome 3: A statistically significant slurry growth is noted but significant solids settling occurs

This outcome indicates that significant gas retention has occurred, but because of the solids settling, may be only a temporary condition. A determination will be made to continue to risk the slurry growth in anticipation that continued solids settling will mitigate the condition or to institute active mitigation techniques. Once this was decided, determine if sufficient waste recovery has occurred to mitigate the high heat tank safety issue. If mitigation of the high heat safety issue has not occurred, an evaluation will be required to trade-off the need for continued waste retrieval to mitigate the high heat tank safety issue against the cost of possibly creating a DST in need of permanent active mitigation to prevent formation of a flammable gas hazard.

Outcome 4: A statistically significant slurry growth is noted and significant solids settling does not occur

This outcome indicates that significant gas retention has occurred and active mitigation techniques are likely to be required. At this point, an evaluation will be required to determine if sufficient waste recovery has occurred to mitigate the high heat tank safety issue. If not, another decision will be required to trade-off the need to continue with mitigation of the high heat tank safety issue against the cost of likely creating or exacerbating a DST in need of active mitigation to prevent formation of a flammable gas hazard. 
WHC-SD-W320-TI-007

Revision 0

\subsection{OPERATIONAL CONSIDERATIONS}

Concerns with gas or steam release in tank $\mathrm{C}-106$ as a result of sluicing appear to be a function of the rate or location of sluicing in the tank. Concerns with gas retention or episodic release of trapped gas in tank AY-102 are a function of the amount and characterization of wastes in the tank. The rate of waste disturbance is important in tank $\mathrm{C}-106$ while the amount and settling behavior of the wastes is important in tank AY-102. The basic control actions for each of the concerns are listed below. The limiting aspects of each will be incorporated into the final recommended process controls.

\subsection{Basic Control Actions}

Tank C-106 Steam Void Release

Precise operational guidance is suggested to handle concerns from this issue. The guidance ensures that the rate of waste removal from tank $\mathrm{C}-106$ is carefully controlled, and that the waste is submerged in WRSS supernate throughout the period of concern. The procedure calls for the controlled removal of approximately 50,000 gallons of tank $c-106$ waste, at which time a waste temperature analysis is expected to show that temperature related retrieval concerns have been mitigated.

The general control actions specify that tank $C-106$ have one to two inches of supernate and that the respective supernate level in tank AY-102 will be held constant during periods of sluicing. This technique will be known as controlled level sluicing. Sluicing commences and continues until one foot of waste in tank $\mathrm{C}-106$ has been removed, or no further waste removal is indicated by material balance measurements at the specified tank levels. Sluicing will be performed using the start-up \& routine single shift operations schedule which provides for 12 hours of sluicing operations in a 24 hour day. The one foot waste depth increment represents a cylinder 65 feet in diameter and one foot thick through the waste in tank $C-106$ representing. a volume of about 25,000 gallons.

At this point, six inches of supernate shall be pumped from tank $\mathrm{C}-106$ to tank AY-102, and the temperatures of thermocouple trees 8 and 14 shall be monitored in tank $\mathrm{C}-106$ for one week. At the completion of the one week period, tank C-106 supernate volume will be further pumped down until about one or two inches remain over the solids (nominally six inches again), and tank $C-106$ temperatures will again be monitored for one week to verify that adequate subcooling has taken place.

Assuming successful completion of the initial two week monitoring period, the controlied tank $A Y-102$ level sluicing sequence will be repeated again (at the new liquid level) until one additional foot of tank $C-106$ waste is removed, or until no progress is evident. At this point, the tank $C-106$ supernate pumping 


\author{
WHC-SD-W320-TI-007 \\ Revision 0
}

and waste monitoring sequence will be repeated again to amount to a two week monitoring period. If two waste removal/monitoring cycles have not retrieved two feet (50,000 gallons) of tank $C-106$ waste, these cycles will be repeated until removal of such a volume is evidenced. It is expected that the tank C-106 waste temperatures will have decayed to subcooled values at the end of the waiting period following the second foot of waste removal.

The required waste temperature performance will be evaluated by Process Engineering to determine satisfactory behavior (Bander, Crea, Ogden 1996 (Draft)). If at the end of the last monitoring period, the amount of waste cooling is found to be insufficient, a decision will be made at that time to either prolong the monitoring period or continue on with further cycles of the controlled tank level sluicing technique until the degree of tank $\mathrm{C}-106$ waste cooling is sufficient.

The material balance model (WHC 1996 (Draft)) predicts a slight shrinkage in the total waste volume contained within the WRSS as sluicing progresses, due mainly to the effect of increasing the salt concentration in the WRSS supernate (which overrides the waste volume growth due to dilution of the salt concentrations in tank $\mathrm{C}-106$ wastes). For the assumed conditions discussed 1 ater, this shrinkage amounts to about 2,000 gallons assuming $100 \%$ of tank C-106 waste is removed, and this amount of supernate volume shrinkage should not constrain the controlled tank level sluicing approach for dealing with the steam release issue.

\title{
Tank C-106 Gas Plume Generation
}

Accident analysis (Plys 1996 (Draft)) has shown that no safety class controls on WRSS operation are immediately required. However, certain routine procedures can be suggested as being applicable to the concern. For example, insuring the HVAC is operational during sluicing operations and perhaps for certain periods of time following termination of WRSS waste recovery operations may help mitigate the consequences of any delayed gas releases from sluicing agitated wastes.

Standard hydrogen monitoring system (SHMS) data for the tank will indicate if hydrogen is being released into the tank head space. Should SHMS data indicate a $1250 \mathrm{ppm}(0.5 \% \mathrm{LFL})$ increase during waste retrieval or during a hold period, or a value $\geq 6250 \mathrm{ppm}(2.5 \% \mathrm{LFL})$ at any time in tank C-106, operation of the WRSS wi1l be discontinued until evaluation of the data and approval for restart by Process Engineering and Tank Farm Transition Projects.

\section{Tank AY-102 Gas Retention/Release Behavior}

Protection against this result is provided by limiting the amount of tank C-106 waste retrieval to no more than $50 \%$ until it can be demonstrated that gas retention is not occurring in the waste (Barton 1996). The $50 \%(100,000$ gallon) limit should prevent a gas retention problem from developing into a gas release event problem. If an analysis at $50 \%$ of tank $\mathrm{C}-106$ waste retrieval indicates no slurry growth, controlled removal of additional waste 


\section{WHC-SD-W320-TI-007}

Revision 0

volumes should be defensible if such removal is required to demonstrate remediation of the high heat waste tank safety issue. Since $50 \%$ of the waste inventory in tank $\mathrm{C}-106$ is about 100,000 gallons, the waste retrieval increment from the steam release concern is limiting until 50,000 gallons of waste removal has been achieved and satisfactory waste temperature behavior is demonstrated.

However, since the waste conditions upon which gas retention problems are initially observed is unknown, it is prudent to take the sequential 25,000 gallons waste volume removal followed by a two week hold period detailed under the steam release issue to additionally determine if gas retention is occurring in the waste before the $50 \%(100,000$ gallon) waste recovery mark is reached. The results of the gas retention monitoring at each hold period will determine how the next retrieval increment is performed. If no gas retention is indicated upon retrieval of $25 \%(50,000$ gallons $)$ of the tank $\mathrm{C}-106$ waste, it will be prudent to move on to a another retrieval increment.

To retrieve waste beyond the 50,000 gallons specified in the steam release concern, a similar retrieval volume followed by a two week monitoring period will be specified. However, in this case the constant level requirement for tank AY-102 will not be in effect and the supernate level in tank C-106 can be maintained at a value for optimum waste retrieval. Additionally, because of the uncertainty of predicting tank conditions at which the onset of gas retention (slurry growth) wi11 occur, the 25,000 gallon volume increment specified under the steam release concern is also appropriate for the slurry growth concern.

Upon satisfactory removal of $50 \%$ (100,000 gallons) of tank C-106 waste, a heat balance measurement will be performed on the WRSS to determine if sufficient source term has been removed from tank $C-106$ to mitigate the high heat tank safety issue. If this heat balance indicates that insufficient source term has been removed from tank $\mathrm{C}-106$, continue with an additional 25,000 galion waste removal/monitoring cycle and evaluate tank AY-102 for slurry growth during the monitoring period. If no slurry growth is noted, the heat balance measurement can be repeated. This cycle may be repeated until sufficient source term has been removed from tank $C-106$.

\subsection{Summary of Process Control Levels}

Table 1 shows the requirements for limits placed on continuous waste removal from tank $\mathrm{C}-106$. The table indicates a volume of waste retrieval allowed to be followed by a monitoring and evaluation period, which must be satisfactorily completed in order to continue on to the next retrieval volume increment. 
WHC-SD-W320-TI-007

Revision 0

\begin{tabular}{||l|l|}
\hline \multicolumn{2}{|c|}{ TABLE 1: Waste Behavior Specifications for Associated Waste Volume } \\
Retrieval Increment
\end{tabular}

\subsection{Measurement of Incremental Waste Retrieval}

The Material Balance Model (WHC 1996) allows indirect process measurements to be used as an indicator of progress of the waste sluicing. The task has now been simply defined to limit the waste retrieval step size to no more than $12.5 \%$ of the total waste volume in tank $C-106$. The material balance methods use two primary measurement variables: tank AY-102 level at specified conditions of the WRSS, and/or the specific gravity of the WRSS supernate. In simplified terms, the material balance uses assumptions about the total mass and conditions of the waste contained within the WRSS. A7so assumed are relationships between solute concentration and the supernate specific gravity as well as a relationship between supernate temperature and specific gravity. Assuming that these quantities are known at any given time (requiring strict accounting of flush water additions, evaporative losses, etc.), enough degrees 


$$
\begin{aligned}
& \text { WHC-SD-W320-TI-007 } \\
& \text { Revision } 0
\end{aligned}
$$

of freedom are specified to determine the amount of tank $C-106$ waste which has been transferred to tank AY-102. If the waste temperature and supernate specific gravity are known, the mass of tank $\mathrm{C}-106$ waste which has been mixed in the WRSS supernate is also known, since all water soluble materials are in solution. Additionally, the mass of tank $\mathrm{C}-106$ waste which has been mixed in the WRSS supernate can also be determined if the supernate specific gravity and the level of tank $A Y-102$ are known, when all the WRSS supernate resides in tank AY-102.

Table 2 shows estimated values of the percentage of tank $C-106$ waste retrieval as a function of tank AY-102 maximum levels and WRSS supernate specific gravities. The case modeled is one that represents good utility. The general assumptions are that the initial amount of tank AY-102 supernate added to the WRSS equals a mass of $1.893 \times 10^{6} \mathrm{~kg}$ of water and $1.0 \times 10^{4} \mathrm{~kg}$ of solute (composed of ions of sodium, hydroxide, nitrate, nitrite and carbonate). This amount is approximately equal to 500,000 gallons of tank $A Y-102$ supernate. The for this assumed composition, the material balance model indicates that $A Y-102$ supernate has a specific gravity of 1.003 at $60^{\circ} \mathrm{F}$. Also specified is a simplified characterization of waste in tank $\mathrm{C}-106$. The waste in tank $\mathrm{C}-106$ is assigned a bulk specific gravity of 1.43 yielding a total mass of $1.066 \times 10^{6} \mathrm{~kg}$. The characterization requires that the waste in tank $\mathrm{C}-106$ be described by mass fractions of: 1) water insoluble solids, 2) water soluble solids (in solution), and 3 ) water. The chosen characterization states that the value of the water insoluble solids mass fraction is chosen as 0.4 . The water soluble solids mass fraction is assigned a value of 0.1 . Consequently, the mass fraction of water in the waste has a value of 0.5 .

The mass fraction of water soluble solids produces several effects on the volumetric and density behaviors of the wastes contained within the WRSS. The water soluble solids (salts) serve to increase the dissolved solids content, and thus the specific gravity, of the liquid wastes (supernate) in the WRSS. Therefore, for a given amount of tank $\mathrm{C}-106$ waste retrieved, higher salt concentrations will produce higher supernate specific gravities and thus reduced supernate specific volumes. (In this case, the volume shrinkage of the WRSS supernate offsets the volume growth of the tank $C-106$ wastes upon dilution by the sluicing retrieval).

With the assumed conditions, it can be seen from Table 2 that the point of $12.5 \%$ tank $C-106$ waste retrieval (corresponding to a cylindrical volume 65 feet in diameter and one foot thick) is indicated when the level in tank AY-102 at $60^{\circ} \mathrm{F}$ increases about 8.5 inches over its initial value, or when the specific gravity of the WRSS supernate at $60^{\circ} \mathrm{F}$ increases by about 0.005 . This relationship basically holds through $50 \%$ waste retrieval, and is largely applicable through greater volumes of waste retrieval. This indicates that at least two measurable process variables can be used to determine the onset of the hold or waste monitoring period for the waste retrieval increment in progress. 
WHC-SD-W320-TI-007

Revision 0

The water soluble solids mass fraction of 0.1 is a useful value. Larger values will result in greater changes in WRSS supernate specific gravity over the course of the retrieval activity, whereas smaller values will produce changes in WRSS supernate specific gravity too small to be detected by available methods. The soluble mass fraction of 0.1 produces a supernate specific gravity change of roughly 0.01 for every $25 \%$ of tank $C-106$ waste volume retrieved. A specific gravity change of 0.01 is at the accuracy limit of the available measurement methods. Therefore, the affect of lower values of water soluble solids mass fraction cannot be measured using methods based on supernate specific gravity alone. In addition, there would be minimal changes in supernate specific gravity as a result of waste retrieval. Therefore, for small values of water soluble solids mass fraction in the waste, changes in tank AY-102 level (i.e. volume) could be attributed directly to the volume of tank $\mathrm{C}-106$ waste retrieved with 1 ittle error in the assumption. In fact, the assumption of additive volumes will be in error by no more than $5 \%$ even if tank C-106 wastes are considered $20 \%$ by weight water soluble salts, when compared to waste with no water soluble salts present.

By comparing the values of maximum tank AY-102 level in concert with the WRSS supernate specific gravity, information beyond the measurement of the amount of waste retrieval may be obtained. Mismatches between measured tank levels and supernate specific gravity may mean that adjustments to the assumed characterization of tank C-106 wastes are required, and/or that adjustments to the mass balance model are needed. Additionally, an analysis of such mismatches may be indicative of other problems such as inaccurate accounting of the system water balance (e.g., flush water volumes added to the WRSS, estimated evaporative losses from the WRSS, and even potentially leaks in the WRSS). 
WHC-SD-W320-TI-007

Revision 0

Table 2

Predicted Waste Retrieval as a Function of Measured Process Parameters

Tabulated values of \% Waste Recovery from Tank C-106:

1. Tank AY-102 level (inches) with 60F supernate during mass balance measurement

2. Total increase in Tank AY-102 level (inches) at $60 \mathrm{~F}$ during mass balance measurement

3. Measured supernate specific gravity at $60 \mathrm{~F}$

4. Measured total increase in supernate specific gravity at $60 \mathrm{~F}$

given the following conditions in the WRSS:

$\begin{array}{ll}\text { mass of water in WRSS not originating from tank C-106 }(\mathrm{kg}) & \mathrm{mw}+\text { mwdelta }=1.8925 \cdot 10^{6} \\ \text { soluble mass in WRSS not originating from tank C-106 }(\mathrm{kg}) & \begin{array}{l}\text { mchem }=1.0000 \cdot 10^{4} \\ \text { mwaste }\end{array}=1.0663 \cdot 10^{6} \\ \text { mass of waste in tank C-106 }(\mathrm{kg}) & \rho=1.4300 \\ \text { bulk specific gravity of waste in tank C-106 } & \text { insf }=0.4000 \\ \text { water insoluble mass fraction of waste in tank C-106 } & \text { solf }=0.1000 \\ \text { Water soluble mass fraction of waste in tank C-106 } & \text { intf }=0.5000 \\ \text { mass fraction of waste in tank C-106 which is water } & \end{array}$

$\%$ of $\mathrm{C}-106$

Retrieved

$\%$.

\begin{tabular}{|l|}
\hline 0 \\
\hline 5.0000 \\
\hline 10.0000 \\
\hline 15.0000 \\
\hline 20.0000 \\
\hline 25.0000 \\
\hline 30.0000 \\
\hline 35.0000 \\
\hline 40.0000 \\
\hline 45.0000 \\
\hline 50.0000 \\
\hline 55.0000 \\
\hline 60.0000 \\
\hline 65.0000 \\
\hline 70.0000 \\
\hline 75.0000 \\
\hline 80.0000 \\
\hline 85.0000 \\
\hline 90.0000 \\
\hline 95.0000 \\
\hline 100.0000 \\
\hline
\end{tabular}

1.2.

totaldepth,

193.8328

197.3642

200.8975

204.4326

207.9693

211.5076

215.0474

218.5887

222.1312

225.6751

229.2201

232.7664

236.3137

239.8621

243.4115

246.9619

250.5132

254.0653

257.6183

261.1722

264.7268
$\Delta$ totaidepth $0, j \quad \mathrm{pl}_{0, j}$

\begin{tabular}{|c|}
\hline 0 \\
\hline 3.5315 \\
\hline 7.0648 \\
\hline
\end{tabular}

7.0648

10.5998

14.1366

17.6749

21.2147

24.7559

28.2985

31.8423

35.3874

38.9336

42.4809

46.0293

49.5787

53.1291

56.6804

60.2326

63.7856

67.3394

70.8940
3.

1.0032

1.0055

1.0077

1.0098

1.0119

1.0139

1.0159

1.0178

1.0196

1.0214

1.0231

1.0248

1.0265

1.0280

1.0296

1.0311

1.0326

1.0340

1.0354

1.0367

1.0381
4.

\begin{tabular}{|c|}
\hline$\Delta \mathrm{l}_{0, j}$ \\
\hline 0 \\
\hline 0.0023 \\
\hline 0.0045 \\
\hline 0.0067 \\
\hline 0.0087 \\
\hline 0.0107 \\
\hline 0.0127 \\
\hline 0.0146 \\
\hline 0.0164 \\
\hline 0.0182 \\
\hline 0.0199 \\
\hline 0.0216 \\
\hline 0.0233 \\
\hline 0.0248 \\
\hline 0.0264 \\
\hline 0.0279 \\
\hline 0.0294 \\
\hline 0.0308 \\
\hline 0.0322 \\
\hline 0.0335 \\
\hline 0.0349 \\
\hline
\end{tabular}


WHC-SD-W320-TI-007

Revision 0

\subsection{Monitored Parameters During Hold Periods}

The Project W-320 Materia] Balance Procedure, T0-320-003 (WHC 1996 (Draft)) describes the procedures by which periodic process measurements will be made on the WRSS. The material balance measurements specified by the procedure are obtained periodically (e.g., daily when adhering to the base case - start-up \& routine single shift operations schedule which provides for 12 hours of sluicing operations in a 24 hour day). At some point after a period of retrieval operations, the material balance measurements will indicate if a $12.5 \%$ waste volume retrieval increment $(25,000$ gallons $)$ has been achieved per Table 2. If so:

3.3.1 Perform Steps 5.1.1 - 5.1.7 of T0-320-003, if the WRSS is not al ready in the established condition.

\subsubsection{Perform Steps 5.1.8 - 5.1.18 of T0-320-003.}

3.3.3 Record the temperatures indicated on thermocouples 1 - 4 (TCl TC4) on Risers 8 and 14 in tank C-106.

3.3.4 Repeat steps 3.3 .2 and 3.3.3 as necessary to determine the trend, if any, displayed by the waste temperatures in tank $\mathrm{C}-106$ or the tank level and supernate specific gravity in tank AY-102 over a two week period. Evaluate the results per Section 3.4 to determine a satisfactory completion of the hold period.

3.3.5 Return the WRSS to service per step 5.1.19 of T0-320-003.

SHMS wi1l also be monitored during hold periods for both tanks C-106 and AY-102. If SHMS data from either tank indicate a $1250 \mathrm{ppm}(0.5 \% \mathrm{LFL})$ increase during a hold period (or during waste retrieval), or a value $\geq 62.50 \mathrm{ppm}$ $(2.5 \% \mathrm{LFL})$, operation of the WRSS will be discontinued until evaluation of the data and approval for restart by Process Engineering and Tank Farm Transition Projects.

\subsection{Data Requirements to Determine Satisfactory Completion of Hold Period}

Satisfactory completion of any hold period for waste monitoring will always require verification that slurry growth is not occurring in tank AY-102 (Barton 1996). A requirement for the first two 25,000 gallon retrieval increments is to demonstrate that temperatures in tank C-106 waste have cooled adequately to allow sluicing to continue (Bander, Crea, Ogden 1996 (Draft)). It is estimated that retrieval of $50 \%$ of tank $\mathrm{C}-106$ wastes should mitigate the high heat waste tank safety issue (Bander, Crea, Ogden 1996 (Draft)). After $50 \%$ ( $100,000 \mathrm{ga} 11 \mathrm{ons})$ of C-106 waste has been retrieved, an obvious requirement for continued retrieval is that it is still required to mitigate 
WHC-SD-W320-TI-007

Revision 0

the high heat waste tank safety issue. Therefore, each monitoring period following $50 \%$ and greater waste retrieval will also require a heat balance to determine if sufficient source term has been removed from tank $\mathrm{C}-106$.

In accordance with estimates (Barton 1996), maximum possible slurry growth in tank AY-102 would be indicated by approximately a 7.5 SCF increase per $12.5 \%$ waste retrieval per day. At the first hold period following $12.5 \%$ waste retrieval, a maximum temperature corrected tank level increase resulting from $14 \times 7.5$ SCF or 105 SCF of slurry growth at the end of the two week hold period, assuming the waste originally in tank AY-102 contributes nothing to this figure. Assuming that this gas is would be trapped at about 1.5 atmospheres pressure, the maximum expected slurry growth expected during the hold period is $(105 \times 7.48) /(1.5 \times 2,750)$ or 0.2 inches (corresponding to 0.4 inches at $25 \%$ retrieval, to 0.8 inches at $50 \%$ retrieval and 1.2 inches at $75 \%$ retrieval). Most likely, any detectable slurry growth rates will be significantly less that this. Therefore, it appears that any statistically justifiable density corrected level increase during the waste monitoring period would have to be conservatively assumed as an indication of slurry growth. Again, al though the potential for problems resulting from slurry growth are not expected unt $1150 \%$ waste retrieval is reached, slurry growth cannot be ruled out based on currently available data, no matter how little waste has been transferred to tank AY-102.

If the initiation of slurry growth is defined as any statistically viable increase in tank AY-102 level during the hold period, a question arises as to what level of slurry growth indicates what volume of trapped gas, if instantaneousiy released, would cause the headspace to reach $25 \% \mathrm{LFL}$ condition. This question is important since non-intrinsically safe equipment will be used to mitigate the condition and therefore, mitigation activities must be established before gas retention in the tank could reach an amount as to cause the headspace to reach $25 \%$ LFL if released into it.

The limiting condition would be the gas release into the headspace volume if the tank were filled to its maximum operating level (corresponding to 55 inches of freeboard). The headspace volume contributed by the dome space and the 55 inches of freeboard comprises roughly $50,000 \mathrm{ft}^{3}$. To achieve a $25 \% \mathrm{LFL}$ condition in the headspace, the hydrogen concentration must be one percent by volume or $500 \mathrm{ft}^{3}$. Since best estimates of hydrogen concentration in gas generated in tank waste is about 50\% of the total (Estey 1996), this would require the release of about 1,000 SCF of gas. Assuming that this volume of gas is trapped in the tank AY-102 waste at 1.5 atmospheres pressure, the critical amount of slurry growth would then be $1000 / 1.5$ or $670 \mathrm{ft}^{3}$, equating to $(1,000 \times 7.48) /(1.5 \times 2,750)$ or slightly less than a two inch increase in tank AY-102 level. 
WHC-SD-W320-TI-007

Revision 0

Another indication of the presence of slurry growth may be revealed by continuous monitoring and analysis of the SHMS dedicated to each respective tank. If a steady state condition exists between gas generation and gas release in tanks $\mathrm{C}-106$ and $\mathrm{AY}-102$, the integrated products of gas concentration times tank ventilation flow rate should be a constant. Slurry growth is not expected during periods of active sluicing (Barton 1996). However, during the hold periods, slurry growth may be indicated by reductions in the total gas volumes exhausted from the tanks, since at least some gas is being stored in the waste as opposed to released from the waste. Although no quantitative control limits can be assigned to this technique at this time, its potential as a process control method is clear. The SHMS results can be regularly monitored and evaluated to detect for the presence of statistically viable trends. If these trends indicate that total gas emission from the wastes contained within the WRSS are reduced during the hold periods, it will constitute evidence of the presence of slurry growth in tank AY-102.

If tank C-106 temperatures (when applicable), tank AY-102 level, and the dedicated tank SHMS indicate that no problems are occurring, the hold period can be declared complete, and the next retrieval increment can begin. If not, continuation of the hold period to allow for further evaluation and/or establishment of active mitigation of waste gas retention must be evaluated. 
WHC-SD-W320-TI-007

Revision 0

\subsection{CONCLUSIONS AND RECOMMENDED OPERATIONAL CONTROLS}

Waste characterization data and the Project Material Balance Procedure form the basis for establishing process measurements which indicate the amount of tank C-106 waste transferred to tank AY-102. Table 2 represents an approximate guide for the measurements to be expected and the associated amount of waste retrieved from tank $\mathrm{C}-106$ assuming all tank levell and specific gravity measurements are corrected to a value of $60^{\circ} \mathrm{F}$.

Figures 1 \& 2 graphically show the information of Table 2 . However, in the Figures, supernate temperature, as opposed to being set at $60^{\circ} \mathrm{F}$, is considered a variable which spans the range of permissible operating temperatures of the WRSS $\left(60^{\circ} \mathrm{F}-120^{\circ} \mathrm{F}\right)$. The Figures are contours which show a dependent variable plotted against two independent variable on the axes. Figure 1 shows the expected maximum level in tank AY-102 (the dependent variable) as a function of tank $\mathrm{C}-106$ waste retrieval expressed as a percentage and supernate temperature (the two independent variables). In a similar fashion, Figure 2 shows the expected supernate specific gravity as a function of tank $\mathrm{C}-106$ waste retrieval expressed as a percentage and supernate temperature.

Although absolute tank levels and supernate specific gravities depend on the volume of supernate in the WRSS, changes in tank level and supernate specific gravity are much less sensitive to a precise accounting of supernate volumes in the system. Assuming that the WRSS contains approximately 500,000 gallons of supernate, variations of $\pm 10 \%$ of this volume will not significantly affect the values of tank level changes as sluicing progresses, and the resultant changes in supernate specific gravity differences due to such a variation could not be detected. Figures $3 \& 4$ show data largely identical to Figures 1 $\& 2$, with the initial contributions from the 500,000 gallons of supernate at $60^{\circ} \mathrm{F}$ removed. The data shown in Figures $3 \& 4$, thus, represent the expected increases above the initial values (tank AY-102 maximum level and supernate specific gravity) recorded prior to the start of any tank-to-tank waste transfer. These values should be sufficient to specify the progress of the waste retrieval unless large changes in the supernate volume (due to excessive flushing, evaporative losses, or supernate leaks) occur during the course of operations. Additional adjustment of these values may be desired if changes in the assumed characterization of tank $\mathrm{C}-106$ wastes are needed to make the predicted data agree with that observed during the course of operations.

Figures 3 \& 4 , therefore, specify the control limits for a given value of tank C-106 waste retrieval and a measured WRSS supernate temperature. $12.5 \%$ tank C-106 waste retrieval is specified as the point during sluicing operations at which the first WRSS hold period is established equating to 25,000 gallons of waste retrieval. Therefore, whenever the material balance measurements specified by T0-320-003 (WHC 1996 (Draft)) indicate a level in tank AY-102 and a supernate specific gravity corresponding to the values indicated for $12.5 \%$ waste retrieval in Figures $3 \& 4$, the start of the corresponding waste monitoring period will be declared. 
WHC-SD-W320-TI-007

Revision 0

\section{Figure 1}

Predicted Maximum Tank AY-102 Level as a Function of Percentage Tank C-106 Waste Retrieval and Supernate Temperature.

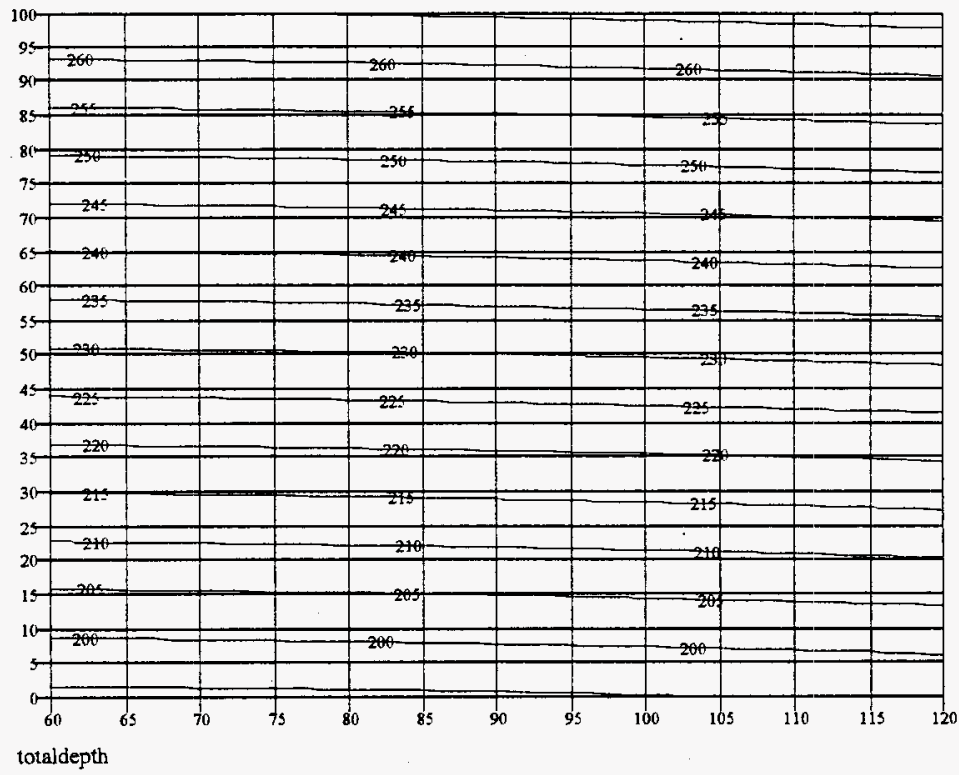

Contour plot of predicted tank AY-102 maximum level versus

Supernate temperature on the $x$ axis, and

Percentage of $\mathrm{C}-106$ waste recovered on the $y$ axis 


\section{WHC-SD-W320-TI-007}

Revision 0

Figure 2

Predicted Supernate Specific Gravity as a Function of Percentage Tank C-106 Waste Retrieval and Supernate Temperature

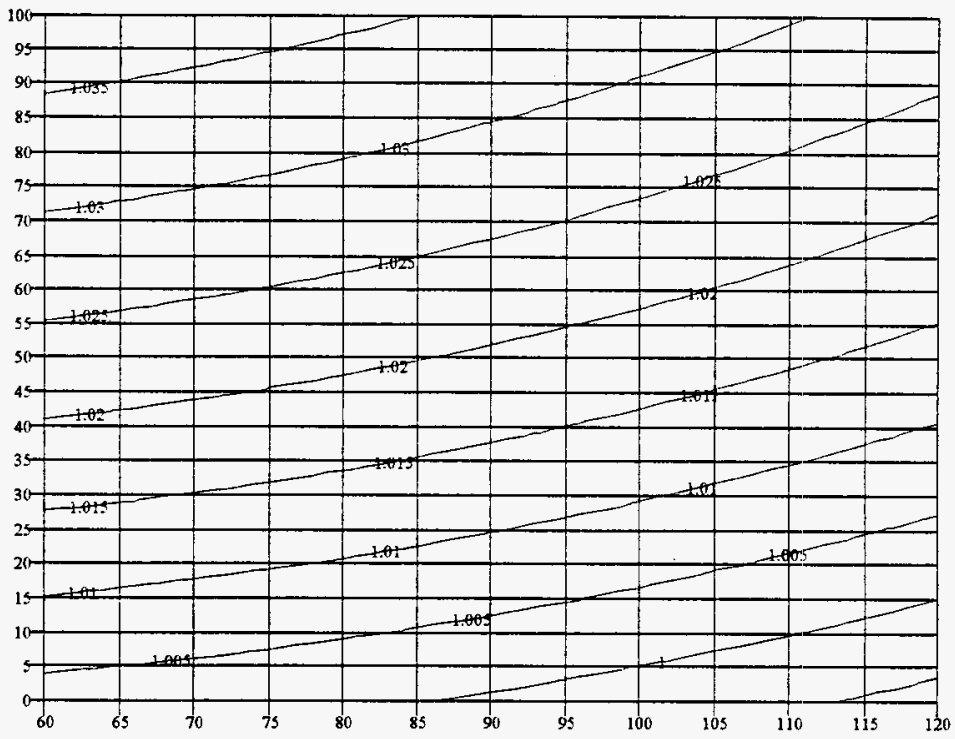

p]

Contour plot of predicted WRSS supernate specific gravity versus

Supernate temperature on the $x$ axis, and

Percentage of $\mathrm{C}-106$ waste recovered on the $y$ axis 
WHC-SD-W320-TI-007

Revision 0

Figure 3

Predicted Increase in Maximum Tank AY-102 Level as a Function of Percentage Tank C-106 Waste Retrieval and Supernate Temperature

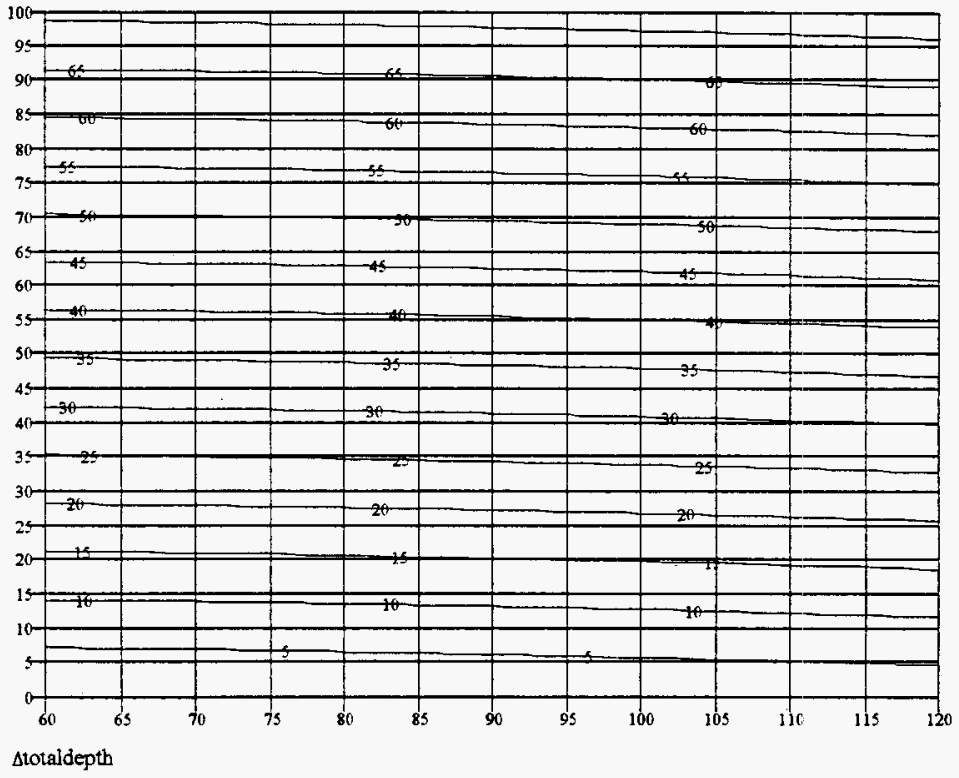

Contour plot of predicted tank AY-102 maximum level increase versus

Supernate temperature on the $x$ axis, and

Percentage of $\mathrm{C}-106$ waste recovered on the $y$ axis 


\section{WHC-SD-W320-TI-007 \\ Revision 0}

\section{Figure 4}

Predicted Increase in Supernate Specific Gravity as a Function of Percentage Tank C-106 Waste Retrieval and Supernate Temperature

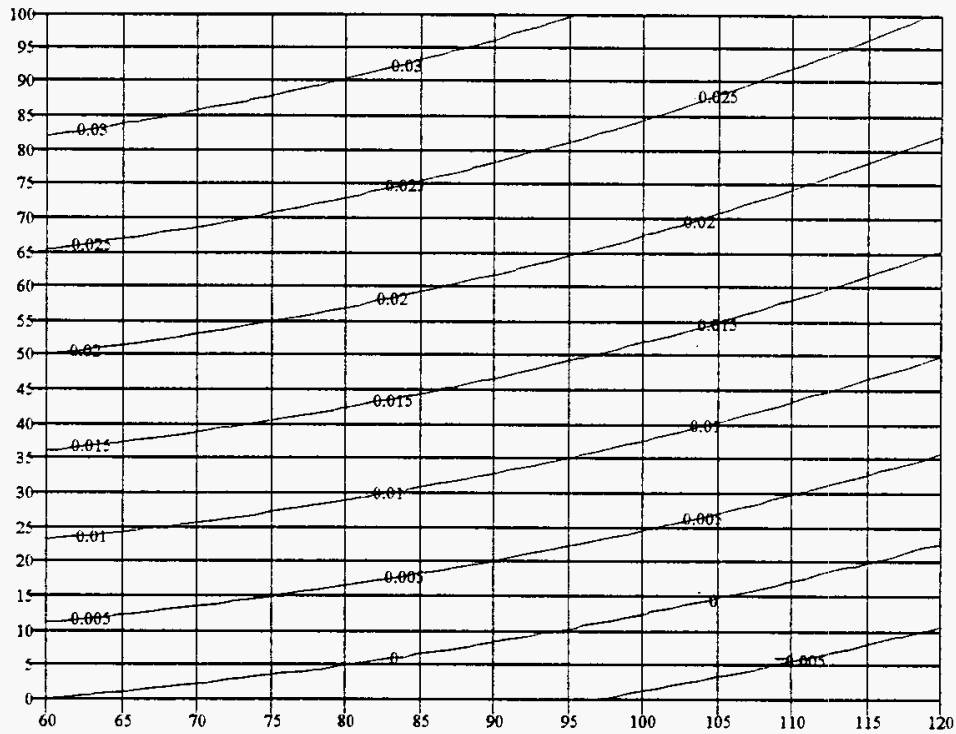

$\Delta \rho]$

Contour plot of predicted WRSS supernate specific gravity increase versus

Supernate temperature on the $\mathrm{x}$ axis, and

Percentage of $\mathrm{C}-106$ waste recovered on the $y$ axis 
WHC-SD-W320-TI-007

Revision 0

If there are mismatches between the measured maximum level and supernate specific gravity and only one of the values indicates that a hold period should commence, a shutdown of sluicing operations may be appropriate until the source of the measurement discrepancy can be identified. It should also be re-emphasized that a detectable response in supernate specific gravity is not expected until 25\% of the waste volume has been retrieved.

As an example, in Figure $3,25 \%$ waste retrieval would be indicated by a measured maximum level increase in tank AY-102 of slightly less than 18 inches at $60^{\circ} \mathrm{F}$, slightly less than 19 inches at $90^{\circ} \mathrm{F}$, or slightly less than 20 inches at $120^{\circ} \mathrm{F}$, when compared to the measured maximum level of the $60^{\circ} \mathrm{F}$ supernate in tank AY-102 prior to the start of tank-to-tank waste transfer. It is unlikely that these level values would be off by more than one half inch unless some unaccounted process upset has occurred. As an example using Figure 4, $25 \%$ waste retrieval would be indicated by a measured supernate specific gravity increase of 0.011 at $60^{\circ} \mathrm{F}, 0.007$ at $90^{\circ} \mathrm{F}$, or 0.001 at $120^{\circ} \mathrm{F}$, when compared to the measured specific gravity of the $60^{\circ} \mathrm{F}$ supernate prior to the start of tank-to-tank waste transfer. Again, any supernate specific gravity change smaller than 0.01 probably will not be detectable.

Using Figures 3 and 4 , waste monitoring periods could be declared at any other chosen increment of waste retrieval, provided the practical limit on the measurement of supernate specific gravity is considered. Once retrieval activities are begun, an ever increasing data base of process measurements will become available. This will allow process engineering to refine the assumed waste characterization and other aspects of the material balance calculations as needed to yield maximum benefit from the predictive method. As such, the control values depicted in Figures $3 \& 4$ will be subject to change.

The end of any waste monitoring period following any 25,000 gallon waste retrieval increment will be specified by Process Engineering following analysis of the performance indicators. The minimum period allotted for this monitoring step is two weeks. Continuation of the monitoring period will be evaluated on a case-by case basis. An example might be that confidence in the absence of slurry growth behavior may be higher after two weeks of observation at the $12.5 \%$ waste removal increment when compared to the two weeks of observation at the $50 \%$ waste removal increment. The waste behavior indicators to be evaluated are:

1. Tank C-106 waste temperatures equilibrate as predicted. This indicator will not be required after $25 \%$ (50,000 gallons) of waste has been removed from tank $\mathrm{C}-106$.

2. The presence of slurry growth in tank AY-102 is ruled out by observation - no statistically significant slurry growth is noted during the hold period. 
WHC-SD-W320-TI-007

Revision 0

3. Analysis of SHMS performance indicates that no gas entrapment/slurry growth is occurring.

4. A WRSS heat balance has verified the need to continue with retrieval activities. This determination is not required unti $150 \%(100,000)$ gallons of waste has been removed from tank C-106.

If the conditions of $1,2,3$, and 4 , where required, are not all met, process engineering will determine at that time whether to extend the hold period for continued evaluation and/or institute active slurry growth mitigation.

As an example, if slurry growth is noted before $50 \%$ waste recovery has been achieved, a WRSS heat balance may be desired to support analysis of what course of action should be taken. The expectation would be one of a decision based on comparing the risk of exacerbating a slurry growth condition in tank AY-102 versus the risk of leaving the high heat waste tank safety issue unmitigated, as well as being able to insure mitigation activities have been initiated in tank AY-102 before two inches of slurry growth is observed. Another example which will require application of engineering judgement will be the observation of hindered solids settling during any two week waste monitoring period and the implications for continuation sluicing activities. 
WHC-SD-W320-TI-007

Revision 0

\begin{tabular}{|c|c|}
\hline PARAMETER & LIMIT \\
\hline Monitoring Period & The minimum monitoring period is two weeks \\
\hline Waste Retrieval & Maximum $25,000 \mathrm{gal}$ between monitoring periods \\
\hline Temperature & $\begin{array}{l}\text { After removal of } 25,000 \text { gal. of waste, six inches of } \\
\text { supernate sha1l be pumped from tank C-106 to tank } \\
\text { AY-102, and thermocouple trees } 8 \text { and } 14 \text { shall be } \\
\text { monitored in tank C-106 for one week. } \\
\text { Then tank } C-106 \text { supernate volume will be punped until } \\
\text { one or two inches remain over the solids, and } \\
\text { temperatures will again be monitored for one week to } \\
\text { verify that adequate subcooling has taken place. } \\
\text { Temperatures in tank AY-102 wi1l continue to be } \\
\text { monitored in accordance with WHC-SD-WM-0SR-004, Rev. } 1 \\
\text { Aging Waste Facility Interim Operational Safety } \\
\text { Requirements. } \\
\text { The required waste temperature performance will be } \\
\text { evaluated by Process Engineering to determine } \\
\text { satisfactory behavior. This indicator will not be } \\
\text { required after } 25 \% \text { (50,000 gallons) of waste has been } \\
\text { removed from tank C-106. }\end{array}$ \\
\hline Specific Gravity & Tank AY-102 maximum 1iquid specific gravity of 1.3 \\
\hline Mass Balance & $\begin{array}{l}\text { The Project W-320 Material Balance Procedure, } \\
\text { T0-320-003 (WHC } 1996 \text { (Draft)) describes the procedures } \\
\text { by which periodic process measurements will be made on } \\
\text { the WRSS. }\end{array}$ \\
\hline Waste Level & $\begin{array}{l}\text { Waste level monitoring capabilities must be available } \\
\text { in both tanks to measure the amount of waste removed } \\
\text { from tank } C-106 \text { and received into tank } A Y-102 \text {, and to } \\
\text { check for slurry growth in tank AY-102. }\end{array}$ \\
\hline SHMS & $\begin{array}{l}\text { If SHMS data from either tank indicate a } 1250 \mathrm{ppm}(0.5 \% \\
\text { LFL) increase during a hold period (or during waste } \\
\text { retrieval), or a value } \geq 6250 \mathrm{ppm}(2.5 \% \text { LFL), operation } \\
\text { of the WRSS will be discontinued until evaluation of } \\
\text { the data and approval for restart by Process } \\
\text { Engineering and Tank Farm Transition Projects. }\end{array}$ \\
\hline
\end{tabular}


WHC-SD-W320-TI-007

Revision 0

\begin{tabular}{|c|c|}
\hline PARAMETER & LIMIT \\
\hline Heat Balance & $\begin{array}{l}\text { Upon satisfactory removal of } 50 \%(100,000 \text { gallons }) \text { of } \\
\text { tank C-106 waste, a heat balance measurement will be } \\
\text { performed on the WRSS to determine if sufficient source } \\
\text { term has been removed from tank C-106 to mitigate the } \\
\text { high heat tank safety issue. If this heat balance } \\
\text { indicates that insufficient source term has been } \\
\text { removed from tank C-106, continue with an additional } \\
25,000 \text { gallon waste removal/monitoring cycle and } \\
\text { evaluate tank AY-102 for slurry growth during the } \\
\text { monitoring period. If no slurry growth is noted, the } \\
\text { heat balance measurement can be repeated. This cycle } \\
\text { may be repeated unti sufficient source term has been } \\
\text { removed from tank C-106. None }\end{array}$ \\
\hline
\end{tabular}




\section{WHC-SD-W320-TI-007 \\ Revision 0}

\subsection{REFERENCES}

Babad, H \& B. A. Crawford, R. D. Schrieber, J. A. Campbe11, G. M. Mong, 1996, "Chemical and Chemically-Related Considerations Associated with Sluicing Tank C-106 Waste to Tank AY-102", WHC-SD-WM-TI-756, Rev. A (Draft), Westinghouse Hanford Company, Richland, Washington.

Bander, T. J., B. A. Crea, D. M. Ogden, 1996 (Draft) ,"Tank 241-C-106 Sluicing Evaluation", WHC-SD-WM-ER-588, Rev. 0, Westinghouse Hanford Company, Richland, Washington.

Barton, W. B., 1996, "Project W-320 Position Paper - Flammable Gas Issue", WHC-SD-W320-SP-002, Rev. 0, Westinghouse Hanford Company, Richland, Washington.

Estey, S. D., 1996a, TANK 241-C-106 RETRIEVAL INDUCED FLAMMABLE GAS PLUME ANALYSIS, (Internal Memo 74A110-96-082 to J. P. Harris, June 10), Westinghouse Hanford Company, Richland, Washington.

Estey, S. D., 1996b, MODELING FOR POTENTIAL GAS RETENTION/GAS RELEASE PROBLEMS IN TANK 241-AY-102 FOLLOWING TANK 241-C-106 RETRIEVAL, (Internal Memo 74A110-96-062 to J. P. Harris, May 8), Westinghouse Hanford Company, Richland, Washington.

Estey, S. D. \& M. D. Guthrie, 1996, "An Analysis of Parameters Describing Gas Retention/Gas Release Behavior in Double Shell Tank Waste", WHC-SD-WM-TI-755, Rev. 0, Westinghouse Hanford Company, Richland, Washington.

Plys, M. G., 1996 (Draft), "Hypothetical C-106 Retrieval-Induced Gas Release and Combustion", (Letter to John Harris and John Conner), Fauske \& Associates, Inc., Burr Ridge, Illinois.

WHC, 1996 (Draft), "Waste Retrieval Sluicing System Material Balance", T0-320-003, Rev. A-0, Westinghouse Hanford Company, Richland, Washington. 


\section{DISTRIBUTION SHEET}

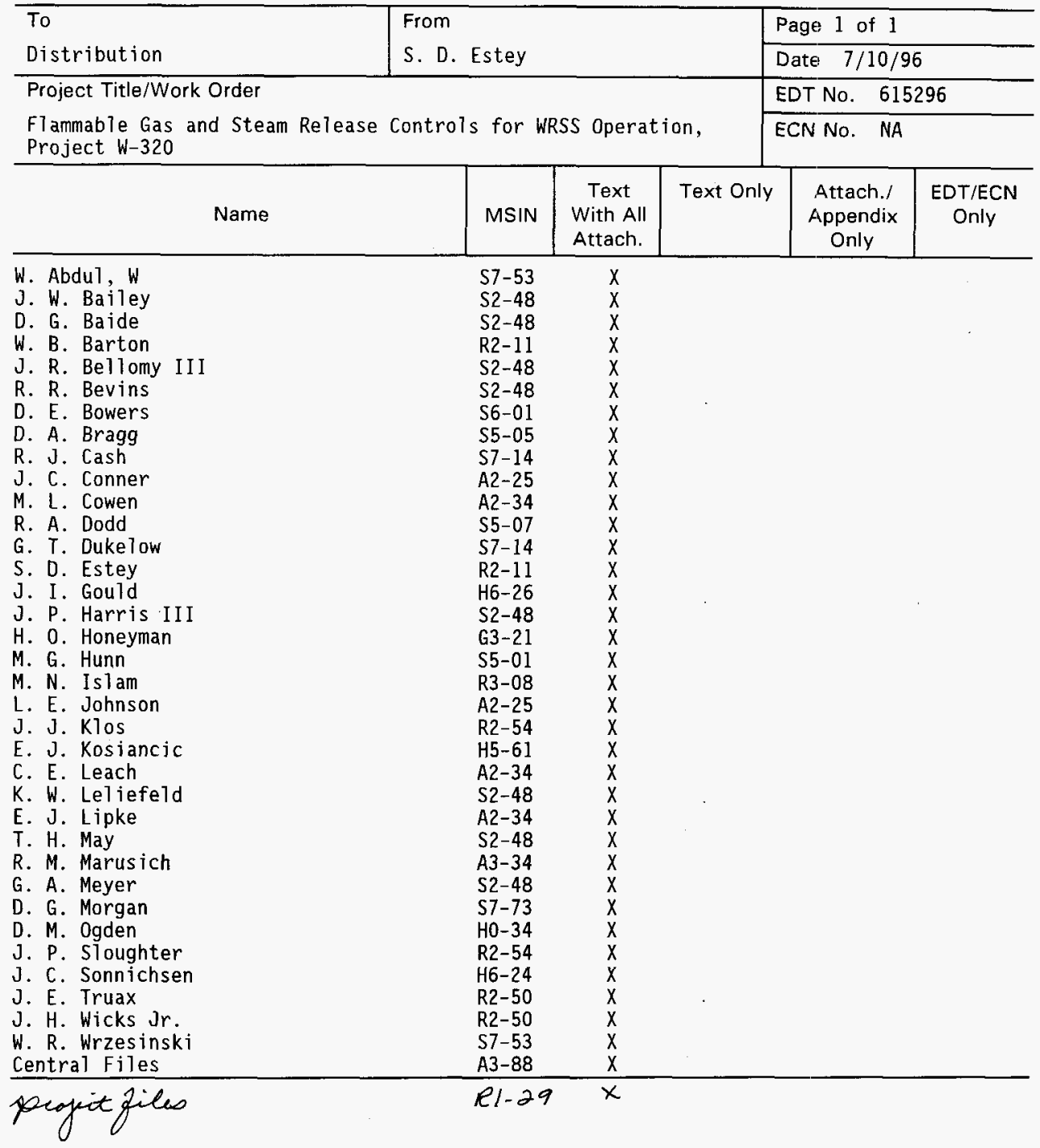

